\title{
FOI, É E SERÁ? \\ USOS DA FÓRMULA DA ETERNIDADE PARA FALAR DO TEMPO NA FILOSOFIA PRÉ-SOCRÁTICA
}

\author{
Celso de Oliveira Vieira ${ }^{\star}$ \\ Universidade Federal de Minas Gerais
}

\begin{abstract}
The so called Eternity Formula is found both in Homer and Hesiod. The speeches of a seer and of the muses are said to inform the things "that are, will be and were". Versions of this formula were also used by presocratic philosophers to describe the temporal aspect of central concepts within their cosmologies. Generally, they use it to convey the eternity of an entity by the affirmation of its existence throughout past, present and future. That is the case of fire in Heraclitus' linear and reciprocal conception of time, of hate and love in the cyclical time of Empedocles, of the intelligence living in an eternal now in Anaxagoras' cosmos, and of the eternal being in Melissus and Parmenides. Nonetheless, each use of the formula has its own peculiarities. The aim of this article is to make a comparative analysis of them, both within the thought of each philosopher as in face of one another. At the end I will propose a general formula of eternity in the presocratic philosophy that points towards an absolute conception of time. Furthermore, I hope to show that such an absolute treatment of time ends up by denying it implicitly or explicitly in a particular type of eternal present. KEYWORDS: Presocratics; eternity formula; time; being; cosmology.
\end{abstract}

^cvb909@gmail.com 


\title{
Introdução $^{\star \star}$
}

\begin{abstract}
Oll
ma das estratégias da composição oral é o uso de ideias prontas que podem ser incluídas para completar versos. Essas fórmulas são estabelecidas, de maneira mais ou menos fixa, como unidades, tal qual uma expressão idiomática. ${ }^{1}$ Com o advento da escrita e o abandono da métrica, amplia-se a possibilidade de alterar essas fórmulas a partir de uma concepção mais crítica do seu significado. Na Grécia antiga a chamada fórmula da eternidade passou por este processo. Em sua versão mais antiga, a encontramos composta pelo verbo 'ser' no particípio presente, futuro e presente precedido pela preposição pró (antes). Desta maneira, os poetas se referiam à eternidade falando de algo que 'é, será e era'. A partir daí vários filósofos pré-socráticos adequaram essa fórmula para explicar como funcionava o tempo em relação às entidades centrais das suas concepções de mundo. O uso foi bem livre. De acordo com o interesse de cada um, eles optaram, por exemplo, por trocar a ordem das palavras ou adicionar advérbios para enfatizar o presente, o passado ou o futuro, a mudança constante ou a estabilidade do que é eterno. A intenção aqui será colocar em evidência o processo por trás dessas escolhas.
\end{abstract}

\section{A fórmula da eternidade na poesia épica}

A ocorrência reminiscente mais antiga de uma versão da fórmula da eternidade se encontra nos poemas homéricos. Na Ilíada I, 70 o poeta a utiliza para definir o adivinho Calcas como o que "sabia o que agora é, o que será, e o que antes era”. Outro uso poético bem similar se encontra

\footnotetext{
$\star \star$ Gostaria de agradecer aos revisores da revista Nuntius Antiquus, cujas críticas enriqueceram em muito a versão final do texto.

${ }^{1}$ Fórmula aqui tem um sentido amplo já que, apesar de uma introdução que trata de maneira breve da tradição oral de composições épicas, o objeto de análise são suas apropriações e alterações feitas pelos pré-socráticos. Segundo a distinção usada por Lord (Lord, 1986, p. 477), a fórmula seria um grupo de palavras que emprega uma mesma métrica para expressar uma mesma ideia. Para ir além desse critério rígido, ele passa a identificar o que chama de um 'estilo formular' (formulaic style) em vários textos e se propõe a examinar a densidade das fórmulas de acordo com sua recorrência em cada texto. Veremos na sequência como a métrica é abandonada pela maioria dos pré-socráticos, mas que, ainda assim, mantém-se neles uma estrutura que remete à poesia épica para se falar da totalidade do tempo.
} 
atestado na Teogonia. No verso 38 Hesíodo utiliza a mesma fórmula para caracterizar as musas que "que dizem o que é, o que será, e o que antes era". Assim, temos:

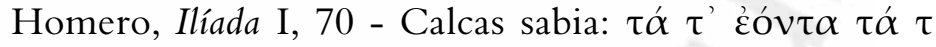

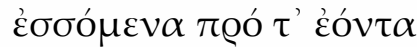

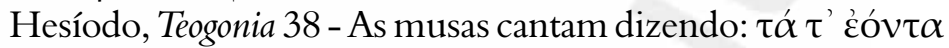

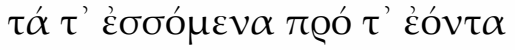

Uma comparação das duas passagens revela como a fórmula era usada de uma maneira bem fixa na tradição oral. ${ }^{2}$ Além de serem formalmente idênticas, elas ainda compartilham um mesmo contexto, na medida em que servem para caracterizar discursos que são especiais, sobre-humanos ou divinos, por romperem os limites temporais. Primeiro, no caso do melhor dos adivinhos e, segundo, no caso das musas, o que diferencia os discursos por eles produzidos é o fato de abarcarem presente, futuro e passado, ou melhor, utilizarem a fórmula: 'o que é, o que será, e o que foi'.

A ordem de apresentação dos tempos também é a mesma. Ela parece vir da experiência humana, já que começa pelo presente (o que os humanos experienciam, o que é), segue para o futuro (o que experienciarão e querem saber antes, o que será) e termina no passado (o que eles já não podem experienciar, mas que constitui as causas do presente, o que foi antes). Essa apresentação revela que o tipo de temporalidade eterna aludida nos dois casos é aquele em que um observador é capaz de contemplar de maneira integral o que normalmente escapa aos humanos, escondido na sequência temporal.

No contexto da Ilíada, por exemplo, todos os humanos ali presentes sabem que há uma peste no acampamento aqueu; no entanto, apenas Calcas está ciente do que fazer para resolvê-la no futuro. Sua vantagem está exatamente no fato de ele conhecer a causa passada da tragédia presente. ${ }^{3}$

\footnotetext{
${ }^{2}$ Assim elas confirmam a definição de Parry para uma fórmula que seria: "uma palavra ou um grupo de palavras empregadas regularmente sob as mesmas condições métricas para expressar uma dada ideia essencial" (Parry, 1930, p. 80). Veremos a seguir que a liberdade métrica, bem como uma variação substancial na ideia a ser expressa, permite aos pré-socráticos manipularem a fórmula como lhes convém.

${ }^{3}$ Segundo Vidal-Naquet, "[a] peste no acampamento aqueu é a transcrição, num registro humano, de uma decisão divina, mas isso, somente Criseu, o adivinho Calcas e o poeta o sabem" (Vidal-Naquet, 1960, p. 57). Vale notar que o tempo
} 
Calcas sabe que a peste é causada pela ira divina, por isso ele propõe que a solução é fazer libações para acalmar os deuses. Eis a utilidade do acesso à eternidade, de uma perspectiva humana. O observador especial que sabe a causa passada do presente pode alterar o futuro. É esse também o ponto de vista que Hesíodo quer acessar quando pede a ajuda das musas para cantar, no presente, a origem dos deuses. O seu objetivo, porém, é menos prático do que o da Ilíada, o que acaba lhe permitindo um tratamento menos funcional da temporalidade eterna.

A perspectiva divina mais absoluta é a diferença essencial entre Calcas e as Musas. Um, apesar de ser o melhor dos adivinhos e ter poderes sobre-humanos, continua sendo um ser humano. Portanto, apesar de acessar futuro e passado, ele tem o uso do seu conhecimento limitado ao presente em que se encontra. As musas, por sua vez, são divindades e, por isso, não precisam partir do presente para acessar o passado e vislumbrar o futuro. Como sua percepção não está presa às constrições espaçotemporais, podemos identificar na escolha de um observador divino um primeiro passo para um tratamento mais absoluto da temporalidade. Apesar dessa mudança, talvez pela fixidez da métrica, Hesíodo não altera nem mesmo a ordem 'humana' de apresentação dos tempos ao usar a fórmula da eternidade. Como veremos a seguir, no caso dos pré-socráticos, cada passo no caminho de um tratamento mais absoluto da temporalidade será expresso por alterações formais importantes.

\section{A fórmula da eternidade nos pré-socráticos}

Em um novo contexto, e com muito mais nuanças, a fórmula da eternidade também foi prolífica no que já pode ser identificado como um discurso filosófico. Variações do uso daquilo que 'é, será e era' podem ser encontradas em Heráclito, Parmênides, Empédocles, Anaxágoras e Melisso. Dentre esses, a ocorrência mais antiga acontece, provavelmente, nos fragmentos do efésio:

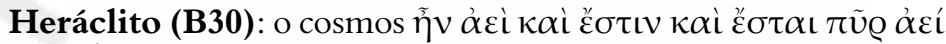
$\zeta \tilde{\omega} \mathrm{ov}^{4}$

não precisa ser cíclico para que o conhecimento do passado ajude no futuro. Um tempo linear, desde que haja uma cadeia causal (mesmo se desencadeada por uma ação divina), também permite esse tipo de intervenção.

${ }^{4}$ As numerações são de Diels-Kranz, as traduções são minhas. B30: "A ordem do 
Em B30 Heráclito diz que o cosmos (a ordem do mundo) "era sempre, é e será fogo sempre vivente". Apesar de seguir o mesmo princípio de tratar da eternidade através do verbo 'ser' usado nos três tempos, essa ocorrência é bem particular. A primeira diferença formal é que os verbos não aparecem na forma nominal. O particípio neutro eónta usado pelos poetas significa 'as coisas que são', mas Heráclito prefere usar formas verbais como ésti. A importância dessa alteração é ainda maior porque o uso do verbo 'ser' é copulativo. Como eimí aqui ainda não tem um uso existencial, é necessário um predicativo para que a sentença faça sentido. O cosmos é, era e será alguma coisa. Despido o texto das qualificações, o que Heráclito diz na passagem se reduz a: 'o cosmos é fogo'. Esta versão simplificada permite notar um traço que será generalizável nas outras ocorrências da fórmula da eternidade na filosofia pré-socrática. As formas do verbo 'ser' em diferentes tempos são usadas para falar não da temporalidade percebida por um observador, mas sim em relação ao elemento ${ }^{5}$ base da cosmologia apresentada.

A mudança para um referente absoluto é destacada ainda por duas outras nuanças da fórmula em B30. Primeiro. Heráclito insere o advérbio aeí (sempre) que enfatiza a descaracterização de qualquer relatividade a um observador humano ou divino enquanto afirma a eternidade absoluta de um cosmos que é sempre fogo. Isso fica ainda mais claro quando, na sequência do fragmento, o filósofo enfatiza que a ordem do mundo não "foi criada por nenhum homem ou nenhum deus". A eternidade do cosmos, portanto, não é pensada em relação a um adivinho, às musas ou a qualquer outro observador. A fórmula expressa a eternidade de uma maneira que se quer objetiva. Postura essa que faz sentido em vista de outros fragmentos de Heráclito. Em B1, na abertura do seu livro, ele não pede ajuda às musas e ainda afirma discorrer "segundo a natureza". Já em B50 ele solicita aos seus ouvintes que "escutem não a ele, mas ao lógos". Diante disso fica evidente que o conteúdo do seu discurso (lógos) independe da perspectiva humana ou da inspiração divina de quem o profere.

Esse caráter absoluto da eternidade é congruente com outra diferença de apresentação em relação à poesia épica. Em Heráclito a

mundo, deste, o mesmo de todos, nenhum dos deuses nem dos humanos criou. Ela era sempre, é e será fogo sempre vivente, abrasando em medidas e apagando em medidas".

${ }^{5}$ Por uma questão de simplicidade o termo 'elemento' é utilizado aqui de maneira vaga para se referir a qualquer coisa ou força que tenha um papel basilar nas cosmologias dos filósofos em questão. 
ordem das palavras não é mais a da experiência humana (presente, futuro e passado), mas sim o que pode se chamar de uma ordem cronológica, que apresenta em sequência passado, presente e futuro. O fogo está sempre em mudança, independentemente de haver observador ou não, e por isso sua caracterização não começa do presente.

O cosmos descrito em B30 "era sempre, é e será fogo sempre vivente (...) se acendendo e apagando em medidas". Trata-se, portanto, de uma eternidade em movimento eterno apropriada a uma concepção mobilista de mundo. Esse movimento permite falar em passado, presente e futuro que podem ser entendidos como momentos de um fogo que estava apagado e irá se acender. Por outro lado, como o fogo aceso voltará a se apagar, é preciso abandonar uma concepção irreversível do tempo. Ao que tudo indica, a cosmologia de Heráclito engloba um tempo retilinear, porém recíproco. Isso quer dizer que passado, presente e futuro retornam na ordem inversa: futuro, presente e passado.

A ordem linear de apresentação da fórmula da eternidade (era, é e será) acrescida da reciprocidade (acendendo e apagando) é perfeitamente congruente com um esquema retilinear apresentado, por exemplo, em B60, onde "o caminho para cima e para baixo é um e o mesmo". Esse caminho linear que vai da mesma maneira que volta é o modelo da mudança eterna do cosmos em Heráclito, formulação conceitual que, por isso mesmo, pode ser usada para entender também sua temporalidade. Se o tempo está atrelado à mudança do fogo, essa mudança fornece um medidor segundo o qual passado, presente e futuro podem ser pensados de maneira absoluta em relação recíproca sem a necessidade de um observador.

Determinado o uso filosófico mais antigo da fórmula da eternidade, é hora de passar a Parmênides, que apresenta a ocorrência seguinte segundo a cronologia mais aceita atualmente:

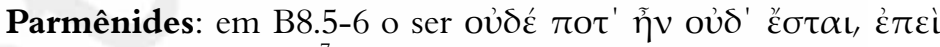

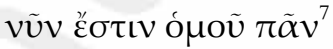

\footnotetext{
${ }^{6}$ Uma relação explícita entre B60 e um modelo cósmico depende da consideração do que diz Diógenes Laércio: "Mudança é o caminho para cima e para baixo e o cosmos vem a ser de acordo com isso" (Diog. Laércio, 9.1.8). Para um exame mais cuidadoso de B60 como um modelo para mudança em Heráclito cf. Vieira, 2010. ${ }^{7}$ B8.1-9: "E só resta ainda relato da senda/ que é, e sobre esta, ainda muito mais signos são/ de que ingênito Ente também imperecível é,/ é inteiro-único, inabalável e inacabável./ Nunca nem era, nem será, pois é agora todo igual,/ uno, contínuo. Pois indagarás dele que origem?/ Por e de onde crescido? De não ente não deixarei/
} 
No fragmento 8.5-6 do poema de Parmênides lemos que "nada nunca foi nem será, uma vez que é agora, igual e total". ${ }^{8}$ A primeira semelhança que se faz evidente em uma comparação com o uso de Heráclito é a recorrência do primado da questão cosmológica. No âmbito monista no qual o ser é o elemento único do cosmos, não surpreende que a eternidade seja aplicada a ele. A diferença mais aparente está no uso predominantemente negativo da fórmula. Em vez de dizer que o ser era, é e será, ele diz, de maneira abreviada, que ele 'nem era nem será, mas é'. A negação inicial de passado e futuro indica que para Parmênides a eternidade só pode ser pensada como um presente eterno. Essa concepção é coerente com uma cosmologia monista na qual, diferentemente do mobilismo de Heráclito, não há mudança e, portanto, não há espaço para qualquer variação temporal. Se o fogo muda, e ele é a base do cosmos, é possível haver mudança temporal, mas como o ser não muda, só lhe resta o presente eterno.

Ao optar por negar a fórmula da eternidade, o eleata define sua cosmologia em oposição à tradição. Além disso, a radicalidade do pensamento monista ainda vem representada na substituição do advérbio aeí (sempre) pelo seu oposto, oúpote (nunca). Aeí foi uma contribuição de Heráclito que, apesar da negação de Parmênides, será recorrente em outros usos pré-socráticos da fórmula. A escolha de oúpote, extremo oposto de aeí, pode, sim, ser uma evidência de que o eleata construiu sua fórmula em oposição à do mobilista. 'O que sempre era' é substituído pelo que 'nunca foi nem nunca será'. Essa posição ontológica extrema reforça a anulação de qualquer existência dos tempos passado e futuro quando pensados em relação ao ser.

Após a apresentação negativa, Parmênides termina seu uso da fórmula com uma conclusão positiva, 'o ser é agora'. Aqui, ele usa um advérbio temporal nûn (agora) para reforçar o presente, em oposição ao 'sempre' preferido por Heráclito. Se olharmos as ocorrências futuras, essa

a ti falar nem pensar. Já que não falável nem pensável/ é o que não é”.

${ }^{8}$ O problema da ordenação dos fragmentos não será relevante para esta investigação, na qual a ordem de apresentação de um argumento é levada em consideração apenas em se tratando de um mesmo fragmento.

${ }^{9}$ Hoy supõe, por exemplo, que "uma outra crítica possível é que Parmênides reagiu com exagero ao hábito de Heráclito de, aparentemente, identificar o que existe em um tempo com o que existe em um outro" (Hoy, 1994, p. 587). Essa suposição de um pensamento criado por oposição é pertinente e corrobora, mas não interfere, no exame realizado aqui. 
será a grande contribuição de Parmênides para os usos subsequentes da fórmula da eternidade: a caracterização do presente como um agora eterno. Ainda de maneira positiva o eleata caracteriza seu ser no presente eterno como igual e total (homoû pân). Isso é importante porque essas características podem ser lidas em relação às negações anteriores. Se o ser é sempre igual, não haveria um passado no qual ele fosse diferente, assim como se ele é total, não há um futuro no qual ele será acrescido de qualquer coisa.

A ordem de apresentação dos tempos também é diferente no poema de Parmênides. Como os poetas, ele desrespeita a ordem cronológica absoluta, mas, diferentemente deles, não começa pelo presente. Pelo contrário, o presente vem no fim, como uma conclusão do resultado das duas negações do passado e do futuro precedidas pelo oúpote (nunca). Nesse caso a estratégia de ordenação dos tempos parece ser mais abertamente retórica. Diversamente dos usos vistos anteriormente, não se trata de repetir o tempo de quem percebe ou emular o tempo absoluto, mas sim de pensar no leitor/ ouvinte que acessará as negações antes de chegar à conclusão do verso. Esta traz o ápice do pensamento com a afirmação do presente eterno igual e total. Diante disso convém verificar se essa interpretação se confirma no resto do poema.

Vimos como a fórmula da eternidade em Parmênides apresenta uma dupla negação do passado e futuro seguida de uma conclusão positiva do presente. Essa mesma estrutura se repete nos versos que antecedem sua apropriação da fórmula. Em B8.3-6 há uma dupla negação da mudança que caracteriza o ser como 'ingênito' e 'imperecível' antes de uma conclusão positiva que o caracteriza de 'inteiro-único'. ${ }^{10}$ A semelhança estrutural reverbera também no conceito. O 'ser' é definido por dois adjetivos privativos, "ingênito e imperecível", que se referem à geração e ao perecimento. Em um âmbito temporal é fácil colocar a geração no passado e o perecimento no futuro. Ou melhor, no caso monista, a não geração no não passado e o não perecimento no não futuro. A semelhança segue na conclusão positiva, pois o fato de o 'ser' ser "inteiro-único (oulomelés)"

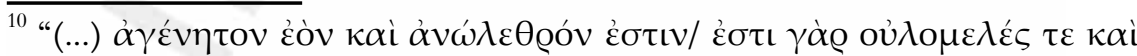

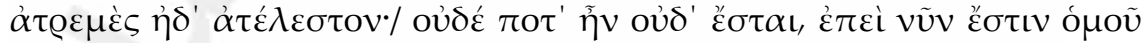

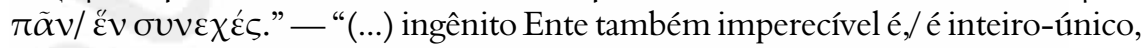
inabalável e inacabável./ Nunca nem era, nem será, pois é agora todo igual,/ uno, contínuo".

${ }^{11}$ Como Kirk, Raven e Schofield, para quem: "Provavelmente o que Parmênides quer aplicar ao que é é a existência em um presente eterno não sujeito a nenhum tipo de distinção temporal. Não é nada claro como ele esperava embasar esta
} 
implica um presente eterno "igual e total". Assim, seguindo a sequência dos argumentos, o mesmo tipo de negação da mudança espacial no ser é que implicaria a sua atemporalidade. ${ }^{12}$ As consequências para cada conceito, porém, são distintas. Sem a mudança o espaço consegue existir em absoluto, em B8.43 ele tem até sua forma esférica descrita. O tempo, porém, pensado em absoluto como um presente eterno, sem estar ligado a um elemento ou à mudança, não consegue se sustentar na cosmologia monista. Dessa maneira Parmênides acaba por negá-lo.

A existência de uma fórmula da eternidade e sua negação em Parmênides ainda podem ser analisadas diante de duas posturas apresentadas no poema. Em B8.8-9 ele diz que não é possível nem falar nem pensar o que não é nas seguintes palavras: "não falável nem pensável é o que não é". Se passado e futuro acarretariam a existência do que não é, a identificação de uma fórmula da eternidade que trata de passado, presente e futuro seria um problema para essa afirmação. ${ }^{13}$ Uma explicação plausível para a existência de termos como passado e futuro, entretanto, surge em passagens como B9.2-3, ${ }^{14}$ em que os opostos como luz e escuridão são ditos serem apenas nomes dados por "mortais de duplas cabeças" (B6.4-5).

Diante disso pode-se defender uma leitura segundo a qual, quando um humano pensa que fala sobre o não ser, ele está, na verdade, falando e

conclusão nos argumentos do fragmento 8" (Kirk, Raven, Schofield, 1983, p. 249-250). Como se espera mostrar aqui, a ordem de exposição da argumentação do fragmento 8 fornece uma boa chave de leitura para a negação do tempo por Parmênides.

${ }^{12}$ A posição defendida aqui, segundo a qual a ontologia precede a negação da mudança, que, por sua vez, culmina com a negação do tempo embasado na ordem de apresentação de B8, vai contra Hoy, para quem "sua [de Parmênides] negação do tempo se assenta, em parte, na sua negação do tempo: a mudança é impossível, em parte, porque o vir a ser temporal é impossível” (Hoy, 1994, p. 578).

${ }^{13}$ Este argumento parece, sim, tratar de um princípio que se pode chamar de lógico na acepção moderna do termo; mais especificamente, parece uma versão da busca pela 'não contradição', pois ele é formulado e aplicado como um princípio ao longo de todo o poema. Mais ou menos como propõe Cordero, que o nomeia de axioma: "Parmênides parte da postulação de um tipo de axioma, que lhe parece evidente (...) e assim o confirma ao mostrar que a sua negação é impossível. É a impossibilidade da negação de seu postulado que converte o axioma em uma tese necessária" (Cordero, 2007, p. 3).

${ }^{14}$ B9: "Todavia desde que nomeadas todas as coisas luz e noite/ e sobre essas e aquelas tais (nomes) por suas potências/ tudo é pleno conjunto de luz e de noite desluzida/ por igual de ambas, logo de nenhuma das duas, o nada". 
pensando o ser de forma errada. De maneira similar, falar e pensar passado, presente e futuro é, segundo Parmênides, mais uma ilusão humana que as pessoas, por não se darem conta de que pretendem algo fadado à falsidade, acabam encontrando formas linguísticas de representar, seja por nomes (passado, presente e futuro) ou por declinações verbais (era, é e será). Dessa forma o argumento não trata de um problema linguístico feito ontológico como muitos propõem, ${ }^{15}$ mas, sim, da correção de um erro ontológico refletido na linguagem. Nessa postura se identifica o uso dos poetas que colocam o tempo da eternidade em relação aos discursos humanos com acesso às divindades. A diferença é que aqui, apesar de Parmênides narrar uma ascensão ao céu na abertura do seu poema (B1.1-11), a perspectiva humana corrente não é divinizada, mas sim criticada.

Apesar da crítica de Parmênides, a fórmula da eternidade sobreviveu. Para ver como o discurso filosófico seguiu se apropriando dela passaremos a Empédocles:

Empédocles: em B21.13 de amor e ódio surgem $\pi \alpha \dot{\alpha} v \theta^{\prime}$ ó $\sigma \alpha \tau^{\prime} \hat{\eta} v$ ő $\alpha \alpha \tau^{\prime} \varepsilon ̌ \sigma \tau \iota ~ \kappa \alpha i ̀ ~ \varepsilon ̌ \sigma \tau \alpha \iota^{16}$

Segundo Empédocles, no amor e no ódio surgem 'todas as coisas que eram, que são e serão'. Como em Heráclito e Parmênides, aqui também podemos reconhecer a aplicação da fórmula da eternidade para caracterizar elementos centrais à cosmologia em questão. A diferença, porém, é que o agrigentino não usa a fórmula para tratar dos elementos básicos que operam no seu cosmos, mas antes para marcar o efeito de tais forças elementares. Amor e ódio geram tudo que 'era, que é e que será'. A diferença é significativa e pode ser vista como uma reação diante do fato de que o tempo tratado em absoluto acabou negado no monismo.

$\mathrm{Na}$ cosmologia de Empédocles, amor e ódio estão além das variações do tempo, apenas as coisas que essas forças geram é que eram, são e serão.

\footnotetext{
${ }^{15}$ Diferentemente de Mourelatos, que defende o contrário: "Em Parmênides certas considerações semântico-epistemológicas levam a conclusões ontológicas" (Mourelatos, 1981, p. 659). A opção aqui é reverter e tomar a ontologia como primordial, ainda que o acesso a ela se dê através do raciocínio lógico expresso pela linguagem.

${ }^{16}$ B21.11-13: "No ódio surgem coisas multiformes e divididas,/ que andam juntas no amor, desejando umas às outras, / já que nestes surgem todas as coisas, as que eram, as que são e as que serão".
} 
O tempo aqui, portanto, se aplica às coisas geradas, mas não aos geradores. Assim como o ser está no presente eterno, amor e ódio também estão além das mudanças temporais, o que muda, nasce e morre são as coisas que deles surgem. Desse modo se identifica uma volta a uma perspectiva relativista do tempo. Uma vez que o tempo é relativo somente ao que é gerado, se o que é gerado não existir, não fará sentido falar de tempo. Esse retorno ao uso mais relativo dos épicos pode, inclusive, ser identificado no fato formal de que o filósofo, que também escreveu em verso, chega a evocar as musas em seus escritos. ${ }^{17}$ Porém essa volta não ignora a inovação de Heráclito, uma vez que ele também aplica a fórmula em relação a elementos constitutivos do cosmos. A relatividade em Empédocles não está ligada a um observador humano ou divino, mas figura no processo de geração e corrupção a partir do qual surgem as coisas do cosmos no passado (as que eram), no presente (as que são) e no futuro (as que serão).

A fórmula da eternidade em Empédocles é o caso mais antigo a apresentar o verbo 'ser' em um sentido existencial. O uso de Parmênides pode ter influenciado essa mudança. Usar o ser como sujeito do verbo 'ser' abre caminho para usá-lo no existencial. Em Heráclito, o cosmos era fogo, é fogo e será fogo; em Parmênides, o ser não era, nem será, mas é igual e total. Em Empédocles, finalmente, as coisas que eram, são e serão não têm predicativo. Isso quer dizer que do amor e ódio surgem as coisas que existiram, existem e existirão. Nisso pode ser identificada outra estratégia de absolutização do tempo.

A ordenação cronológica da fórmula da eternidade vista em Heráclito se repete em Empédocles. Ele também não segue a sequência da experiência humana, mas sim a ordem absoluta de passado, presente e futuro. A semelhança, no entanto, não implica uma mesma concepção do tempo. Ainda que em uma mesma sequência, essas duas eternidades podem ser constituídas de maneiras distintas. A chave para a diferenciação está em como passado, presente e futuro seguem se alternando para constituir a eternidade. Em Heráclito, como vimos, o tempo segue linear e recíproco, enquanto que em Empédocles a concepção é outra. Em B17.1213 (complementado pelo Papiro de Estrasburgo a), o filósofo oferece uma imagem de como amor e ódio interferem nas coisas: "[E]las [as coisas] jamais param de mudar continuamente, neste sentido elas estão sempre

\footnotetext{
${ }^{17}$ Cf. B3a: "E a você, bem lembrada musa virgem de brancos braços, eu peço: traga as coisas corretas para as criaturas de um dia escutarem". No gesto de se nomearem os humanos as 'criaturas de um dia', sua temporalidade limitada é, inclusive, enfatizada de maneira poética.
} 
em um ciclo que não muda". Aqui fica claro que o tempo é pensado de maneira cíclica ${ }^{18}$ para explicar a constância da eternidade. A comparação entre um tempo cíclico constante ou linear recíproco merece ser abordada mais de perto.

No caso do efésio, 1) passado, 2) presente e 3) futuro retornariam sobre o mesmo caminho na sequência contrária 3) futuro, 2) presente e 1) passado. Em Empédocles, por sua vez, o futuro fecharia o ciclo ao se unir com o passado, gerando a seguinte sequência 1) passado, 2) presente, 3) futuro, 1) passado, 2) presente, 3) futuro e assim por diante. Neste sentido a mudança contínua constitui um ciclo que, ele mesmo, não muda. Essa constância faz todo sentido, uma vez que, ao contrário de Heráclito, para quem o fogo está sempre se acendendo e apagando em medidas (B30), em Empédocles os quatro elementos base da cosmologia permanecem sempre na mesma quantidade. ${ }^{19}$ "Nada é subtraído ou adicionado" (B17.30) dos elementos, o que altera é apenas a sua relação de acordo com o predomínio do amor ou do ódio. Assim a mudança segue um ciclo e não um caminho linear recíproco.

Outro fator que a apresentação de Empédocles deixa mais claro é como, no caso dos pré-socráticos, o tratamento dado ao tempo está subordinado à cosmologia. De modo distinto do contexto épico, a eternidade aqui é um objeto marginal. A discussão atribui primazia ao funcionamento dos elementos cósmicos primordiais, nesse caso, com amor e ódio gerando todas as coisas. É apenas porque as coisas vêm a ser no passado, no presente e no futuro que o verbo 'ser' é utilizado nesses três tempos para englobar a eternidade. $\mathrm{O}$ foco é mesmo explicar como elas vieram, vêm e vão vir a ser.

Pensar a temporalidade relativa às coisas geradas, como em Empédocles, e também em relação ao elemento base da cosmologia, como

\footnotetext{
${ }^{18}$ Essa concepção de tempo cíclico fornece ao tempo a imagem espacializada de uma circunferência. Essa imagem espacial de uma circunferência foi muito explorada pelos antigos e aparece tanto em Heráclito quanto em Parmênides com versões muito próximas que merecem um estudo mais cuidadoso. Heráclito, em B103, diz: “[P] is o começo e o fim são o mesmo sobre a periferia do círculo". Em Parmênides, B5, lemos: "Indiferente para mim é/ donde comece, pois lá mesmo, outra vez, retornarei”. Como a leitura proposta aqui é de um tempo linear recíproco em Heráclito e do tempo negado em Parmênides, esses fragmentos seriam lidos como ligados apenas à espacialidade: em Heráclito, indicando mais um exemplo de união de opostos e, em Parmênides, indicando que o ponto do seu poema é único. Porém não haverá ocasião para tratá-los aqui.

${ }^{19}$ B17.29-30: "Eles (os quatro elementos) dominam em turnos, à medida que o tempo revolve, e nada é adicionado ou subtraído deles”.
} 
em Heráclito e Parmênides, são aspectos reconhecíveis nos fragmentos do próximo filósofo a ser analisado, Anaxágoras:

Anaxágoras: em B12.20-21 a inteligência ordena ó тoĩ $\alpha$ ع́ $\mu \varepsilon \lambda \lambda \varepsilon v$

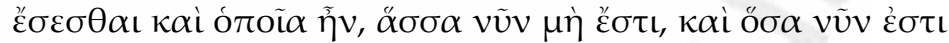

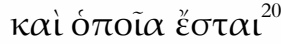

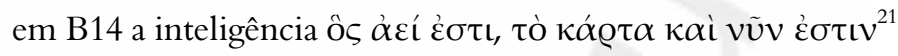

Em B12.20-21 Anaxágoras diz que o noûs ordena as coisas que "estavam a ponto de vir a ser, as que eram e que agora não são, e também as que são e que vão ser". A semelhança com o uso de Empédocles é que a fórmula da eternidade aqui não é aplicada ao elemento base da ontologia, mas, sim, às coisas com as quais esse elemento se relaciona. Para ele, o nô̂s é quem ordena todas as coisas, sendo que esse 'todas as coisas' é expresso pela mais detalhada das versões da fórmula da eternidade. $\mathrm{O}$ filósofo se esforça para não deixar nenhuma possibilidade fora do escopo da ação ordenadora da inteligência. Ela ordena o que estava a ponto de (1.émellen) vir a ser (2. ésesthai), o que já foi (3. ên $)$ e que não é (4. mè ésti) mais e ainda o que é agora (5. nûn esti) e vai ser (6. éstai). Encontramos aqui uma lista de variações do verbo 'ser' que aparece no futuro infinitivo médio na forma ésesthai (2) e éstai (6), no imperfeito (3), no presente indicativo com negação (4) e sem negação (5).

Desta maneira, Anaxágoras usa pares de formas do verbo 'ser' (com ajuda de 1. méllo) para dar conta da sua complexa visão da totalidade do tempo em relação às coisas. Ele começa tratando do futuro do passado (aquilo que estava a ponto de vir a ser), passa ao passado do presente (o que já foi e não é mais) e chega ao futuro do presente (o que é e será). Assim o filósofo dobra a precisão da fórmula tradicional para falar do tempo das coisas que estão submetidas à mudança. Ele julga importante enfatizar que o passado teve um futuro (que poderia ter acontecido ou não), que o presente teve um passado (que já não é mais) e que vai ter um futuro (que vai acontecer). Uma perspectiva que considera como estando submetidas ao tempo também as coisas que poderiam, mas não vieram a

${ }^{20}$ B12.18-22: "A inteligência entende todas as coisas misturadas, separadas e dissociadas. A inteligência ainda ordena as coisas que estavam a ponto de vir a ser, as que eram e que agora não são, e também as que são e que vão ser".

${ }^{21}$ B14: "A inteligência, que é sempre, com certeza também é agora quando todas as outras coisas são, no que está reunido, no que está apartado e no que está separado”. 
ser, bem como aquelas que não são mais, é condizente com a postura de um filósofo que acha que geração deveria ser chamada de união e corrupção de separação (B17), ${ }^{22}$ uma vez que as mudanças nas coisas não passam de rearranjos no cosmos.

Segundo o uso da fórmula da eternidade por Anaxágoras, cada tempo parece trazer a totalidade dos três tempos. Passado, presente e futuro foram, são e serão, cada um deles, um presente com seu passado e seu futuro próprios. Assim, diferindo do uso dos épicos e dos outros pré-socráticos, o tempo relativo às coisas que existem deve ser considerado não da perspectiva de um observador humano ou divino nem de forma absoluta, mas, sim, em relação aos vários tempos de todos os observadores possíveis. Por exemplo, o nosso passado deve ser analisado também do ponto de vista de alguém para quem esse passado era presente e o presente era o futuro. Isso culmina em um uso da fórmula da eternidade adicionado de mais possibilidades a cada tempo tratado.

Além do tempo em relação às coisas que existem, vimos em Heráclito e Parmênides que há também a possibilidade de pensar o tempo em relação a um elemento base de uma cosmologia. Anaxágoras não se furta a essa tarefa ao caracterizar o seu nô̂s. Sua estratégia, porém, é oposta àquela usada para a eternidade com relação às coisas. Para falar da inteligência ele opta por reduzir a fórmula tradicional da eternidade. Em B14 Anaxágoras diz que o "noûs (inteligência) é sempre e, por certo, é agora". Nesta ocorrência vemos uma alteração radical na fórmula da eternidade. Esse uso bem particular prescinde dos tempos passado e futuro aplicados ao verbo 'ser' para explicar a temporalidade da inteligência. Vale notar que os tempos omitidos são justamente os negados por Parmênides. A eternidade aqui é dita simplesmente pelo verbo eimí (ser), também existencial como em Empédocles, na terceira pessoa do presente.

Em vista do uso dos poetas e dos pré-socráticos anteriores, essa escolha parece indicar uma consequência lógica no percurso de absolutização do tempo. Heráclito abandonou a perspectiva humana. Uma vez que não se pensa o tempo em relação ao humano, não faz sentido falar de uma eternidade pensada a partir de um presente, mas, sim, de um presente em mudança eterna. Em Parmênides a absolutização leva à negação de passado e futuro. Em relação a algo que não muda, nada nunca era, nem será. Empédocles, por sua vez, abandonou o copulativo. Uma

\footnotetext{
${ }^{22}$ B17: "Os gregos não entendem corretamente a geração e a corrupção. Nada é gerado ou se corrompe, mas apenas é misturado ou separado das coisas que existem. Portanto, seria correto chamar a geração de união, e a corrupção de separação”.
} 
vez que a existência não é a existência de uma qualidade, não é preciso predicá-la. Daí, então, Anaxágoras percebe que, sem a perspectiva humana e sem que o elemento seja afetado pelo tempo, não faz mais sentido pensar em passado e futuro aplicados a ele. O noûs, no seu caso, não era nem será, ele simplesmente é. Estamos diante do tipo mais absoluto de eternidade, o agora eterno.

Para apresentar esta condição, Anaxágoras prefere repetir e reforçar a forma presente do verbo 'ser' (eimí), em vez de apresentá-lo no passado e no futuro. A inteligência "é sempre e é agora”. É como se ele reduzisse a fórmula da eternidade a uma redundância significativa. A eternidade não era, é e será, ela é, é e é. Prova da necessidade consciente de ênfase é o uso adverbial de tò kárta. $\mathrm{O}$ advérbio, comum em grego jônico, tem a mesma raiz de krátos (força), e é usado para indicar veemência diante de verbos, adjetivos ou outros advérbios. Assim o ésti é repetido e reforçado, sempre no presente, em detrimento de uma variação temporal.

Este pensamento aparece atestado na combinação dos advérbios temporais utilizados nesta ocorrência da fórmula. Anaxágoras usa tanto aeí (sempre), como Heráclito, quanto o nûn (agora) de Parmênides. Esta combinação adverbial constrói uma definição da eternidade como um aquiagora (nûn) que é (e está) sempre (aế). A eternidade de existência desse noûs independe da sequência do tempo. Assim se caracteriza uma inteligência que está aqui sempre pensando o agora. De maneira que em Anaxágoras o verbo eimí, que em grego engloba os sentidos tanto de 'ser' quanto de 'estar' do português, parece tender mais para o significado locativo. Sem a variação entre passado e futuro fica a conclusão de que o noûs está sempre presente.

Neste ponto da investigação surge uma pergunta. Seria mais difícil negar o espaço do que o tempo? Vimos que em Parmênides a temporalidade do 'ser' estático é negada, mas sua espacialidade não. Ele tem, inclusive, sua forma esférica descrita. De maneira análoga, Anaxágoras nega a variação temporal da fórmula da eternidade aplicada ao noûs sem, no entanto, negar seu lugar no espaço. Uma evidência dessa preferência pelo espaço é que o seu ilimitado, em B1, é exemplificado como um ilimitado em tamanho, tanto em grandeza quanto em pequenez, sem se preocupar com limites temporais. ${ }^{23}$ Essa posição se opõe à de Parmênides, que apresenta um ser espacialmente delimitado em formato de esfera. A eternidade seria a ausência de limites temporais, mas Anaxágoras vai além, ao enfatizar a ausência de limites espaciais do noûs.

\footnotetext{
${ }^{23} \mathrm{~B} 1$ : "Todas as coisas estavam juntas, ilimitadas tanto em quantidade quanto em pequenez, pois o pequeno também era ilimitado".
} 
Anaxágoras fornece uma versão positiva da fórmula da eternidade para caracterizar o presente eterno apresentado de maneira negativa em Parmênides. Vejamos agora como outro filósofo monista, Melisso, apresenta sua versão positiva da fórmula:

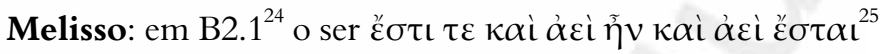

Segundo Melisso (B2) o ser "é, sempre foi e sempre será". Mais uma vez a fórmula é utilizada para caracterizar o elemento base da cosmologia em questão. Como se trata de um monista, o significado do uso se assemelha bastante ao de Parmênides: o ser é o que é eterno. Isso pode ser visto na sequência de B1, em que Melisso mostra que o problema de distinguir passado e futuro em relação ao ser é que, se houver passado, teria que haver algo antes do ser. Se fosse assim o nada existiria, o que é um problema, porque, segundo um tópos comum da filosofia pré-socrática usado pelo monismo, "nada poderia ter vindo a ser do nada" (B1). ${ }^{26}$

No aspecto formal, entretanto, há muitas diferenças entre os dois monistas. O primeiro tempo apresentado por Melisso é o presente, que no eleata vem por último. Na sequência, são apresentados passado e futuro, diferentemente dos poetas que, apesar de também começarem pelo presente, seguem para o futuro antes de voltar ao passado. Trata-se, portanto, de uma oposição formal, mas não conceitual, em relação ao uso

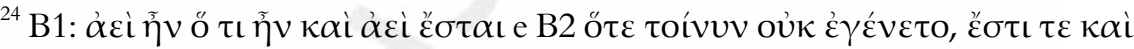

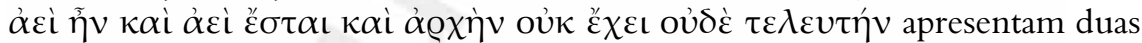
versões muito próximas da fórmula da eternidade. A diferença de B1 é que, em vez do presente, o passado é repetido, ao se dizer que o que "sempre foi, foi e sempre será”. Esse caso também aponta para uma inversão do uso de Anaxágoras, ao suprimir o presente e ao garantir a eternidade do passado e do futuro. Como a interpretação é a mesma, de tempos alongados que perdem a necessidade de variação, esse caso não será analisado em particular.

${ }^{25}$ B2.1-3: "Uma vez que não foi gerado, ele é, sempre foi e sempre será. Ele não tem origem nem fim, pois é ilimitado".

${ }^{26}$ Mourelatos tem a seguinte concepção da diferença entre Melisso e Parmênides. "O ponto crucial para ele [Parmênides, em oposição a Melisso] não é alteração, movimento, transfiguração, redução por nascimento ou morte ou, no caso, por desunificação. É antes que todas as formas de mudança, incluindo nascimento e morte, envolvem um recurso ao 'que não é"” (Mourelatos, 1981, p. 656). Isso pode ser um motivo para a negação do tempo em Parmênides ser mais absoluta do que em Melisso, mas, em suma, as posições dos dois monistas parecem ser bem próximas.
} 
da fórmula por Parmênides. Melisso começa apresentando o presente, que, seguindo o monismo, será eterno e sem mudança. Além disso, ele ainda utiliza aeí duas vezes. O mais comum dos advérbios usados nas fórmulas da eternidade não só foi introduzido pelo mobilista Heráclito, como foi também substituído por 'nunca' pelo monista Parmênides. Nesse caso, no entanto, um outro monista opta por aplicá-lo ao passado e ao futuro, na sequência do presente. Dessa maneira, em vez de suprimir passado e futuro, Melisso os alonga até a eternidade através do advérbio. É assim que ele une os três tempos para formar um presente único. Se o que foi foi sempre, e o que será será sempre, então eles são o mesmo que o que é (sem a necessidade de uma qualificação adverbial). Desse modo o uso da fórmula em Melisso caracteriza uma tentativa formalmente oposta de fazer o mesmo ponto de Parmênides. Eles mostram por meio da eternidade estática a impertinência de separar passado, presente e futuro.

$\mathrm{Na}$ escola monista podemos ver, então, duas estratégias de exposição de um mesmo pensamento. Para falar do presente eterno em que o ser se encontra, Parmênides adota uma via negativa com uso do advérbio 'nunca', enquanto Melisso percorre uma via positiva com ajuda do 'sempre'. Parmênides teria usado a fórmula da eternidade de maneira contrária à de Heráclito para expor sua ontologia contrária ao mobilista. O insucesso dessa estratégia do eleata, porém, pode ser corroborado pelo uso dos outros pré-socráticos que adotaram uma via positiva de apresentação da fórmula da eternidade. Esse predomínio da tradição sobre Parmênides pode ter influenciado Melisso na opção de fazer o ponto da ontologia monista mediante um uso positivo da fórmula da eternidade.

A repetição de aeí, bem como a supressão do nûn, ainda indica outra coisa. Finalmente parece que o caráter espacial foi suprimido no tratamento da eternidade. O que está em questão nesse uso do ser que sempre foi e sempre será não é a mudança ou não mudança de algum elemento, mas apenas a temporalidade do próprio ser. Isso pode ser comprovado pela sequência do fragmento na qual Melisso explica que o ser não tem origem nem fim, sendo, portanto, ilimitado. Esse tipo de ilimitação avança em relação àquele apresentado por Anaxágoras. $\mathrm{O}$ monista nega os limites de uma perspectiva explicitamente temporal: não há começo nem fim. Anaxágoras, por sua vez, negara os limites espaciais, enfatizando que não havia a menor das pequenezas nem a maior das grandezas. Esse parece ser um ganho da absolutização do ser no discurso ontológico do monista. Aqui o tempo passa a ser tratado de maneira totalmente independente do espaço. Essa característica ainda permite uma diferenciação conceitual entre a concepção dos dois monistas aqui analisados.

Em B5 Melisso diz que "se (o ser) não fosse um, ele teria um limite 
com alguma outra coisa”. Talvez por ter vindo após Anaxágoras, que negara um limite espacial ao noûs, Melisso não tenha visto problema em também negar um limite espacial para o ser. O ser não tem limite temporal, já que passado, presente e futuro são sempre. De maneira análoga, e mais radical que Parmênides, o ser tampouco tem um limite espacial, pois se tivesse, teríamos que admitir a existência de alguma outra coisa. Isso seria uma consequência lógica do monismo, que Parmênides não teria reconhecido ao supor uma figura esférica para o seu ser. A absolutização, então, de tempo e espaço culmina, aqui, na negação de ambos.

\section{O resultado da comparação}

A apropriação da fórmula da eternidade percorre o abandono de uma perspectiva humana em prol de um uso absoluto do conceito do tempo. O observador humano (Calcas em Homero) torna- se divino (as Musas em Hesíodo) e depois desaparece (nenhum dos deuses ou homens em Heráclito). A fórmula então passa a ser aplicada aos elementos que seriam eternos em cada cosmologia: o fogo em Heráclito, o ser em Parmênides, o amor e o ódio em Empédocles, a inteligência em Anaxágoras e o ser em Melisso. A questão temporal deriva da existência desses elementos no cosmos. É a partir da afirmação de que algo existe que se pergunta quando isso existe e daí aparece a questão do tempo de existência. Essa questão é respondida de acordo com o entendimento que cada teoria tem do funcionamento do cosmos.

A diferença dos elementos e das cosmologias vem evidenciada nos advérbios relacionados à fórmula da eternidade. Em Heráclito a referência a um observador feita na poesia épica cede lugar ao temporal aeí (sempre)

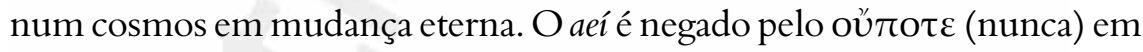
Parmênides, que afirma o nûn (agora) único do ser estático. Depois disso tanto aeí quanto nûn são usados por Anaxágoras para caracterizar seu agora eterno. Este aspecto também é endossado por Melisso, que faz passado e presente eternos com o aeí para construir seu presente ilimitado.

Essa mudança é refletida também na ordem de apresentação dos tempos que começa, da perspectiva humana, com presente, futuro e passado nos poetas, e passa à ordenação cronológica de Heráclito, na qual passado, presente, futuro, presente e passado formam uma mudança linear recíproca. Em Parmênides a negação de passado e presente culmina na apresentação do presente agora eterno. Já Empédocles volta à ordem cronológica, mas para descrever o ciclo constante passado, presente, futuro, passado, presente e futuro. Em Anaxágoras, ainda na ordem cronológica, temos a 
descrição mais detalhada segundo a qual todos os tempos têm em si os outros três. O passado tem o passado do passado, o presente do passado e o futuro do passado, assim como o presente e o futuro. Em Melisso, o presente é apresentado primeiro, para então virem passado e futuro, que são eternizados de modo a extinguir qualquer limite entre eles.

A comparação dessas variações em cada versão da fórmula revela vários pontos em comum que permitem uma generalização do seu uso na filosofia pré-socrática.

\section{Uma fórmula geral}

Se quisermos estabelecer uma estrutura geral para a fórmula da eternidade que englobe todas as suas ocorrências e apropriações nos présocráticos será preciso adotar uma perspectiva bem mais ampla que aquela da poesia. Eis uma proposta:

A fórmula da eternidade consistiria no verbo 1) 'ser' utilizado em pelo menos 2) três tempos 3) com adição ou não de advérbios a fim de significar 4) passado, presente e futuro (não necessariamente nessa ordem) para falar da 5) eternidade de um elemento base da ontologia ou das coisas que este gera.

Dada a definição geral, convém listar as particularidades mais recorrentes:

1) A única exceção ao uso do verbo eimí (ser) é o uso de méllo (estar a ponto de) para indicar o futuro em Anaxágoras.

2) No caso das formas do verbo 'ser', a maior ocorrência nos présocráticos é do trio ên , ésti, éstai, que são formas do eimí, respectivamente, no passado (imperfeito), presente e futuro, todos em terceira pessoa. A segunda ocorrência de Anaxágoras (B14) escapa a essa definição por apresentar apenas o tempo presente. No entanto, a exceção parece justificada, na medida em que ela só funciona em contraposição com os outros usos que se encaixam na definição.

3) Entre os advérbios, os mais frequentes são o aeí (sempre) e o nûn (agora) utilizados quatro vezes cada um, respectivamente, em três e dois filósofos diferentes. Heráclito inaugura o uso do aeí e Melisso o utiliza duas vezes, enquanto Parmênides inaugura o nûn e Anaxágoras o usa três vezes.

4) A ordem mais comum de apresentação dos tempos é a cronológica, que apresenta passado, presente e futuro (era, é e será) com três ocorrências em cinco. Parmênides e Melisso são as exceções.

5) O objeto mais comum da eternidade, quando se trata do elemento 
da cosmologia proposta, é o 'ser' (mas isso porque dois dos filósofos que aparecem são monistas). Em dois casos também o objeto da eternidade são as coisas geradas no cosmos.

Esta generalização permite, sim, ver nesse grupo variado de pensadores um modo de pensar bem próximo que responde a um problema comum: o de explicar um cosmos eterno que funciona sempre da mesma maneira. A resposta a esse problema também é generalizável, trata-se de um presente eterno. Vejamos agora as peculiaridades de cada resposta.

\section{Vários presentes eternos}

Os filósofos pré-socráticos explicam o tempo na sua cosmologia com uma espécie de presente eterno adequada a cada cosmologia apresentada. Entender o que é um 'presente eterno', no entanto, é uma tarefa mais difícil do que construí-lo em uma fórmula discursiva. ${ }^{27}$ De maneira geral esse seria o tipo de temporalidade absoluta que descreve um cosmos eternamente regido por um mesmo modo de operar. $\mathrm{O}$ modo de operar do cosmos, entretanto, varia de cosmologia para cosmologia. Isto faz com que também o presente eterno que o caracteriza varie. Diante disso os modelos discursivos analisados acima podem ser resumidos assim:

O presente eterno de Heráclito caracteriza um cosmos que está eternamente em mudança linear de um estado de fogo mais apagado para um mais aceso. Esta concepção se encaixa em um monismo móvel cuja mudança recíproca é causa da união de opostos.

Em Parmênides, o presente eterno é a negação de passado e futuro como condições diferentes do presente. Assim se entende o tempo de um ser estático, completo e eterno, no qual qualquer mudança espacial ou temporal provocaria a existência impossível do que não é.

O presente eterno de Empédocles se baseia na constância de um tempo cíclico no qual amor e ódio geram alterações a partir de uma quantidade fixa dos quatro elementos básicos terra, água, fogo e ar.

Para Anaxágoras, o tempo da inteligência é um agora que dura para sempre. Assim se caracteriza a posição da inteligência que compreende o ilimitado composto de coisas que se unem e se separam.

\footnotetext{
${ }^{27}$ Por exemplo, Hoy, que se pergunta: "Se Parmênides nega a aplicação de conceitos do passado e futuro à realidade, que conceito de presente pode sobrar?” (Hoy, 1994, p. 594). Mas, apesar de concordar com a negação do tempo em Parmênides, outras leituras de um presente eterno serão propostas aqui.
} 
Em Melisso, o presente eterno é a ampliação de passado e futuro até que eles sejam o mesmo que o presente. Assim, o ser sem limites espaciais também acontece em uma eternidade sem limites temporais.

\section{Conclusão}

Os poetas pensavam na eternidade a partir da perspectiva de um observador, seja humano com poderes divinos (um adivinho), seja divino dando poderes aos humanos (as musas). Já Heráclito, encabeçando o pensamento filosófico, adotou uma perspectiva mais absoluta que prescinde de um observador. Ele usa a eternidade que atravessa todos os tempos para explicar a constituição do cosmos, que, para ele, era, é e sempre será fogo se acendendo e apagando em medidas. Parmênides nega o 'sempre' da cosmologia mobilista de Heráclito, ao dizer que o ser nunca era e nunca será. $\mathrm{Na}$ conclusão positiva do seu argumento, ele diz que o ser é agora. Empédocles não aplica a eternidade ao elemento base do seu cosmos, mas antes às coisas que amor e ódio geram. Assim ele fornece uma nova perspectiva na qual o que gera está além do tempo, que só se aplica ao gerado. Anaxágoras adota as duas perspectivas. Para falar das coisas que o noûs entende, ele constrói a versão mais complexa da fórmula da eternidade com as coisas que estavam a ponto de ser, as que eram, mas já não são mais, e as que são e que serão. Por outro lado, ele usa a fórmula da eternidade de maneira mais sucinta ao aplicá-la ao noûs ele mesmo. Segundo Anaxágoras inteligência é agora e é sempre. Assim, ele usa os dois atributos usados por Heráclito e Parmênides para mostrar o tempo do nô̂s, que seria um 'presente eterno'. Após esse exemplo de uma versão positiva de negação do tempo, Melisso apresenta uma versão positiva da fórmula da eternidade em uma ontologia monista, ao caracterizar o ser como um ser que é, e sempre foi e sempre será. Assim ele usa o advérbio usado por Heráclito, para expor a mesma posição de Parmênides, sem precisar recorrer ao 'nunca'.

A tentativa de adotar uma perspectiva absoluta interdita o entendimento do tempo como uma sequência linear irrevogável. Nenhuma das concepções cosmológicas na filosofia pré-socrática pode propor uma absolutização do tempo segundo a perspectiva humana. A concepção absoluta de um passado irrevogável, um presente da experiência e um futuro que não chegará não faz sentido sem se postular o ponto de vista de um observador. Porém, esta absolutização não tem consequências positivas para a temporalidade, já que as várias formas de presente eterno que cada cosmologia apresenta constituem, em última instância, uma negação do tempo. Ao ser aplicado a forças ou entidades que são a base 
do cosmos, o tempo não se sustenta em absoluto e acaba reduzido a uma ou outra forma particular de presente eterno. A conclusão cosmológica da qual este movimento de pensamento se aproxima é que, do ponto de vista cosmológico, o tempo é impossível.

\section{Referências}

DIELS, H.; KRANZ, W. Die Fragmente der Vorsokratiker. Berlin: Weidmann, 1960/ 1961. Vol. 1.

CORDERO, N. Tertium non datur: Anais de filosofia clássica, Rio de Janeiro, vol. 1, n. 1, p. 1-17, 2007.

HESIOD. Theogony. English Translation by Hugh G. Evelyn-White. Cambridge Mass.: Harvard University Press, 1914.

HOMER. The Iliad. English Translation by A. T. Murray. Cambridge Mass.: Harvard University Press, 1924.

HOY, R. Parmenides' complete rejection of Time. The Journal of Philosophy, New York, vol. XCI, n. 11, p. 573-598, 1994.

KIRK, G.; RAVEN, J.; SCHOFIELD, M. The Presocratic Philosophers. Cambridge: Cambridge University Press, 1983.

LORD, A. Perspectives on Recent Work on the Oral Traditional Formula. Oral Tradition, Columbia, vol. 1, n. 3, p. 467-503, 1986.

MOURELATOS, A. Pre-socratic origins of the principle that there are no origins from nothing. The Journal of Philosophy, New York, vol. 78, n. 11, p. 649-665, 1981. PARRY, M. Studies in the Epic Technique of Oral Verse-Making. I. Homer and Homeric Style. Harvard Studies in Classical Philology, Cambridge Mass., 4, p. 73147, 1930.

VIDAL-NAQUET, P. Les temps et les dieux. Revue de l'histoire des religions, Paris, vol. 157, n. 1, p. 55-80, 1960.

VIEIRA, C. Um modelo para mudança em Heráclito. CODEX 2.2, Rio de Janeiro, p. 118-136, 2010. 